\title{
Banking System Performance on Actual Stage of Economic Development (A comparison Analysis of Banking Systems of Albania and Kosovo)
}

\author{
Msc. Qefsere Kupina \\ PhD Candidate - European University of Tirana \\ Email:qefsere@gmail.com \\ Prof. Dr. Drini Salko \\ Lector on Faculty of Economy and Agribusiness, Agricultural University of Tirana \\ Email: drinisalko61@gmail.com \\ Doi:10.5901/mjss.2015.v6n2p345

\begin{abstract}
Developments of the last decade on the banking systems of Albania and Kosovo are reflecting extensive growth with some intensive actions. This can be observed on the extended network of banking activities and also on the new contemporary products and services in the banking markets of two countries. This process, is affording the direct and indirect impact of global financial crisis affecting both banking systems. The clearest indication is related to the increase in the non-performing loans. This paper focuses on the analyses of the banking activity during the last decade on Albania and Kosovo and the recent performance of banks. The banking systems developer and its performance in both countries is taking into the consideration the comparison of the data based on the statistical information on their monetary authorities. Furthermore, here are giving some findings, conclusions and recommendations for further improvements on the future performance of two banking systems.
\end{abstract}

Keywords: banking system; economic development; macroeconomic indicators; deposits; loans

\section{Introduction}

The banking system activities in Albania and Kosovo are well specified and regulated within their constitutional acts. Both systems within their responsibility are very similar, which primary objectives have to achieve, to promote and maintain price stability. The beginning of banking system operation in these two countries is characterized by prior sensible situations. In Albania, the system begins immediately after the political and economic changes of the years 19911992.While in Kosovo the banking system starts immediately after the war ended in 1999. Albania and Kosovo are members of the International Monetary Fund, the first since 1991, and the second from 2009.

Developments in the banking system of Albania and Kosovo during the last decade can be characterized as extensive developments and somewhat intense. This is seen as the expansion of banking in both countries as well as providing modern banking services in their respective markets of both countries. On the other hand, this development is facing direct or indirect impact of the global financial crisis on the banking systems of the two countries. This influence is evident in the increase of non-performing loans.

The focus of this paper is to analyze the expansion of the financial institutions and particularly the development of banking systems in the last decade of Albania and Kosovo as well as their performance in recent years. The objective of this paper is that, through analysis of developments in the banking market in Albania and Kosovo to provide common features and specific in both countries. On the other hand, economic integration between Albania and Kosovo has been relatively fast and one of its directions is also banking market. In Albania, the banking system is developed as a result of years of experience, while, in Kosovo system itself in relatively new. In this context, commercial banks operating in Albania have opened their branches in the Kosovo market, thus becoming part of the banking market in the country.

In this context, we are going to analyze indicators of banking development, especially the performance of the banking system in both countries and also aiming their comparability. Moreover, we intend to give some conclusions and recommendations regarding the performance of the two banking systems in the future.

On the other hand, this paper is among the first attempts to directly compare the banking systems in Albania and Kosovo. Selected indicators in the future may be added and detailed, to better explain developments. While this effort of ours is trying to find space points that respective regulatory authorities need to improve in order that the formal liberalization of the Albania-Kosovo relations is associated with the promotion of the best developments in each country, 
achieving a common market, which of course can be more competitive with policy coordination. However, the basis of this initiative is the current levels that in the banking system will continue to be analyzed by the weight of assets and liability items of the total banking system.

A comparative analysis will serve us as a benchmark regarding activities, structures and performance of banking systems in these two countries, since both systems within their responsibility seems to be very similar.

Continual improvement of banking systems and their positive impact in economic development would be of interest of Government of two countries, because of the role that banking system has in development of overall financial system of the countries.

\section{Developments in the Banking System of Kosovo and Albania}

Two-levels of the banking system in Albania and Kosovo have a short history watching in the context of political and economic developments. In Albania, the system begins immediately after the political and economic changes of the years 1991-1992 which began with the deployment of the Bank of Albania as the central bank and some commercial banks. While, in Kosovo as a former unit of the ex Yugoslav federation, after 1990 the banking system was based on the operations of the National Bank of Kosovo, which operated as a separate unit of the National Bank system (Central). After, the war ended in June 1999 and the declaration of independence was achieved in 2008, Kosovo began to rebuild and to develop two- levels of the banking system.

After, a bitter experience of the loss of deposits in banks of the former - Yugoslavia, the banking system in Kosovo, begins from zero. Kosovo began creating the new authorities such as "The Banking and Payments Authority of Kosovo" (BPK). The institution was based in Prishtina, created by the United Nations Mission in Kosovo (UNMIK), which task was to administer and supervise the banking sector of the country. Immediately were rebuilt and developed, two levels of the banking system in Kosovo, its Central Bank and commercial banks. It is worth to be cited the progress achieved during the first years of operation. The banking sector has developed rapidly, by including in operation seven commercial banks. An establishment of the financial sector is thought to be applied the best practices and international standards. The law, no.03IL-209 on "Central Bank of Republic of Kosovo ", has been approved by Kosovo Assembly on the 27 July 2010.

After, the global financial crisis of 2008, the financial sector continued operation without any significant disruption despite the unfavorable conditions in the global financial sector. It is important to emphasize, that Kosovo during 2009 was one of the rare countries in the region that indicated positive GDP rate of 3.8 percent, though lower, comparing with the previous year. This was a result of exercising basic financial activity by the institutions operating in Kosovo and very low exposure to instruments with higher globally risk. The effects of the financial crisis were reflected with highlighted scales of the pension system ${ }^{1}$, and specifically in Pension Savings Trust (KPST), which in 2008 recorded a decrease in the value of abroad investments. The positive returns to KPST investments of 2009 shows share among pension fund's assets in September 2009 reached at 13.3 percent of total financial sector assets by comparing with 12.7 percent in September 2008.

As a result of the global crisis the financial intermediation activity of banks was decreased, which was a direct result of the crisis in the real sector of the economy. By September of 2009, the growth trend of the financial sector continued as for the number of institutions, as well as for the value of assets. The number of financial institutions in September 2009 was 69 compared to 67 in September 2008. The banking sector in Kosovo in 2009 operates with eight commercial banks (table 1). The ownership is dominated by six foreign banks and two domestically owned, managing around 74.8 percent of assets, the banking sector remains the main pillars of the Kosovo financial sector. Financial sector assets in September 2009 not included CBK, achieved at euro 2.6 billion (increase of 16 percent), comparing with the same period of the previous year.

Table 1. Number of financial institutions

\begin{tabular}{|c|c|c|c|c|c|c|c|}
\hline & 2007 & 2008 & 2009 & 2010 & 2011 & 2012 & 2013 \\
\hline Commercial Banks & 7 & 8 & 8 & 8 & 8 & 9 & 9 \\
\hline Insurance Companies & 10 & 10 & 11 & 11 & 13 & 13 & 13 \\
\hline Pension Funds & 2 & 2 & 2 & 2 & 2 & 2 & 2 \\
\hline Financial Auxiliaries \& Microfinance Institutions & 46 & 45 & 46 & 49 & $34+20$ & $38+17$ & $39+17$ \\
\hline
\end{tabular}

Source: CBK, Bulletin of the financial sector, Prishtina 2010 and Annual report 2010, 2013

1 Pension system was established in accordance to UNMIK Regulation 2001/35 and consists three categories : Basic Pension, Kosovo Pension Savings Trust and Supplementary Emplyer Pensin Funds 
The financial sector grew slowly in 2010 comparing with 2009. The total value of assets of the financial sector without considering CBK reached 3.2 billion in 2010 which represents an annual increase in $13.7 \%$ compared with $24.1 \%$ annual growth of 2009. The main actors in the financial sector continue to be commercial banks and pension funds, managing $77 \%$ and $15.5 \%$ of total financial sector assets. The rest of the assets were $4.3 \%$ up to microfinance institutions, Insurance companies, $3.1 \%$ and financial auxiliaries $0.2 \%$.

In 2011, there is not recorded any significant change in the structure of the Kosovo financial systems, In terms of the participation of its components. The main pillar of financial sectors remains commercial banks (8) by managing 76.3 percent of total assets of the sector. The number of financial institutions that operate in Kosovo did not indicate any crucial change.

Banking sector in Kosovo during 2012 increased the number of commercial banks of nine (9), comparing with 2011 which was eight (8). However, the structure of ownership remained unchanged, seven (7) banks have foreign ownership and two (2) domestic ownership. No changes, shown in the number of insurance industry and pension funds. And, the financial auxiliaries' institutions, rise of four (4) more, which was 34 in 2011. The number of microfinance institutions is reduced in 2012 in 17 from 20 that were in 2011.

Following, in 2013 the banking system has not shown any remarkable difference from previous years as the number of banks participating in the system as to its structure. Actually, banking systems, consist 80 financial institutions, one new financial auxiliaries entered. The two figures as follows show the trend of the expansion of financial institutions (figure 1) and participation of sectors in total assets of the financial system (figure 2). We see the picture (figure 1), which indicate a slight trend of increases in numbers of financial institutions during the 2007-2013 periods, that presents a stable banking sector among others developed sectors in Kosovo.

Figure 1. Expansion of financial institutions in Kosovo

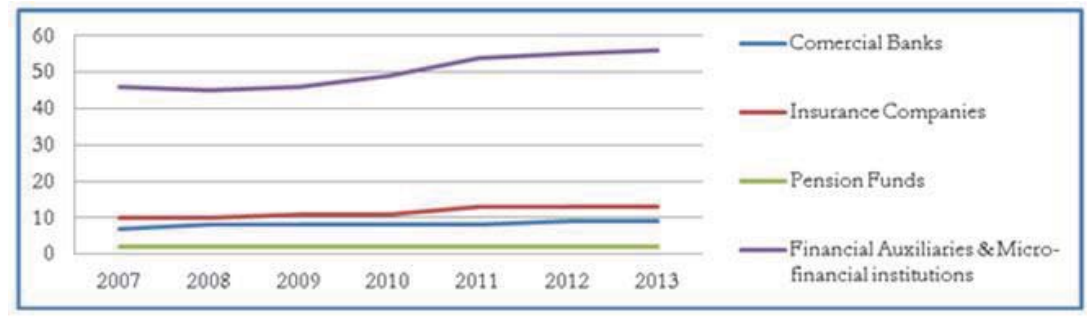

Source: Annual reports of CBK; Graphic adapted from the authors

The following view indicates some information about participation in sectors in total assets of financial systems. It is clear that banking systems represent the largest share of asset structure, followed by pension funds which show increased participation in 2013 to 21.7 from 19.6 percent in 2012.

Figure 2. Structure of assets of financial sector by sector

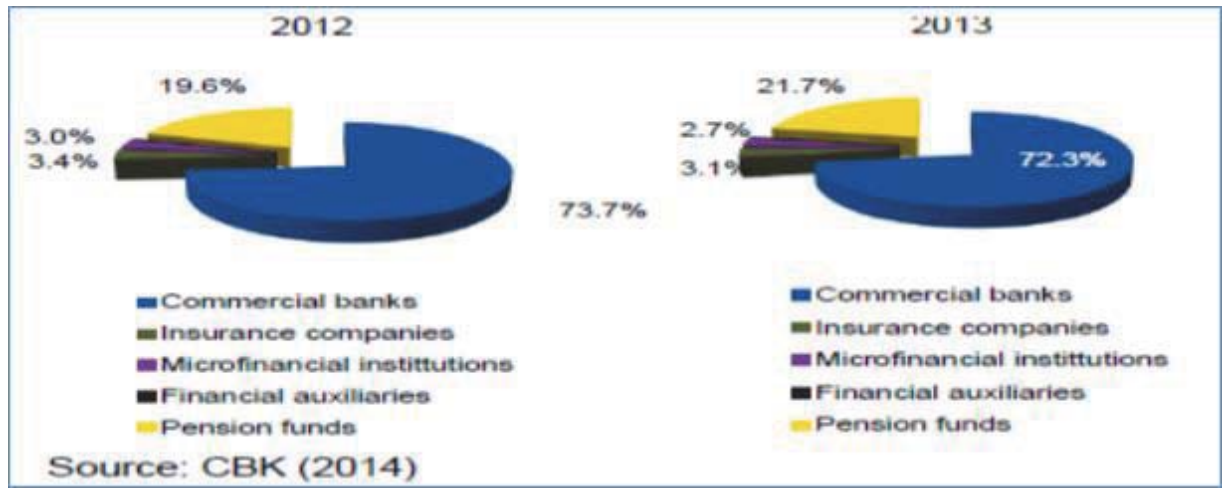

Source: CBK, Annual Report 2013 (CBK, 2014) 


\section{Banking Sector Structure}

During 2009 in Kosovo, commercial banks were obligated to undertake to measure to reduce their operational expenditures of the slowdown in the intermediary activity of the banking system. In 2010, the banking system expanded its infrastructure; therefore the number of branches" and sub- branches" of commercial banks reached 303, which indicate for 16 raised comparing to previous years. The structure of the banking system in Kosovo, in 2010 was similar to that of the last year, as for the number of banks as well as by their ownership structure. In Kosovo the banking market operates with eight commercial banks, of which six were foreign-owned and two domestic owned. Below we will see the participation of banks in total banking sector assets with local capital and foreign capital.

Figure 3. The participation of foreign and domestic banks in total banking sector assets

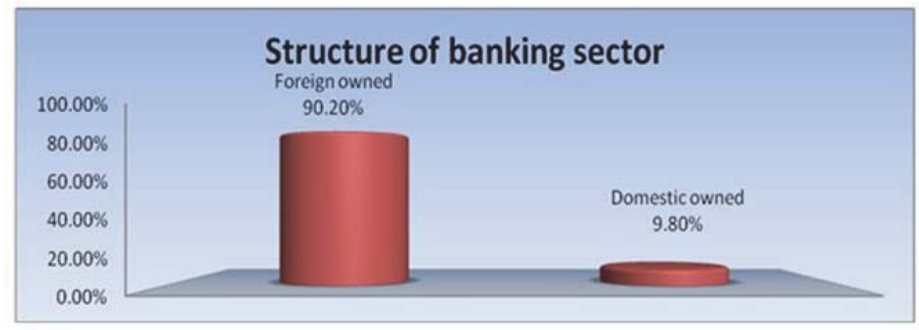

As, see from the figure presented above, the share of foreign banks in total banking sector assets in December 2010 was 90.2 percent, while domestic banks manage 9.8 percent of total assets. Foreign capital in Kosovo, mainly are originating from European Union countries, such as Germany, Austria, Slovenia, Turkey etc. The banking system in Kosovo continues to be characterized as a high degree of market concentration on / of the three largest banks that manage 90.2 percent of total assets (and also to market loans and deposits) of the banking sector. If the degree of concentration is compared to the same period of 2009, with the participation of the three largest banks that in total asset was 91.1 percent we observe a decline, which is attributed to the rapid growth of assets of smaller banks. These, because, the slowdown of growth assets, especially in loans, has been more highlighted from large banks.

In 2011, the number of the commercial banks and ownership remains unchanged from the previous year. The high share of foreign banks is also reflected in the structure of the total assets of the banking system, where 89 percent of the total assets consist of assets of foreign banks, while the remainder belongs to two local banks. Although there was no entry into any new bank of the banking market, in much there was recorded entry into new capital from outside the banking system of the country. The European Bank for Reconstruction and Development (EBRD) has purchased about 10 percent of the shares of Bank for Business (BPB), which is dominated by local ownership.

Despite, the new bank joined the Kosovo banking system, during the year 2012, and there are no changes to show in bank ownership in comparison with previous years. Almost in the same position of the previous year stands the share of foreign banks of 89.5 percent of total assets / an asset / the asset of the country's banking system, and the rest continues / continued to be managed by domestic banks. Banking infrastructure remained unchanged from the previous year in terms of expansion. The number of branches" and sub-branches" of the commercial banks represents a similar level to the previous year.

No any significant changes in the structure of the banking sector in Kosovo, shown during 2013. It has been noted, the degree of market concentration of the banking sector has decreased from / to faster growth of assets of smaller banks. As a result, in 2013 the share of assets of three largest banks of the country declined from around 2 percent in comparison with previous years, (69.3\% in 2012, while $67.4 \%$ in 2013).

The decrease, shown in the figure below through, Herfindahl-Hirschman Index - HHI , include the same period of latest four years . 
Figure 4. HHI for assets, loans and deposits

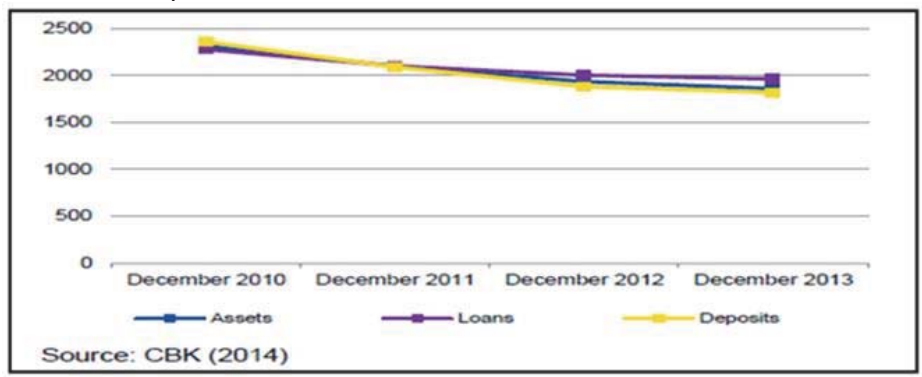

Source: CBK, Annuel Report, 2013

\section{Development of Banking Activity in Albania and Kosovo}

The economic development of Albania and Kosovo is characterized by a modest increase with the exponential growth of real GDP from 3.1 and 4.5\% respectively. During the period 2010 - 2012, the dates indicate a level almost twice higher of the Albanian economy, compared to Kosovo. This is shown by the Gross Domestic Product, and the level of loans and deposits of the banking system in the two countries.

The same as the previous periods, deposits represents the main financing source of the banking sector. Deposits in 2012 were about 6.7 billion euros in Albania and 2.3 billion euros in Kosovo, while the respective banking systems have supported the economy with loans at 4 and 1.8 billion euros. A year after both banking system shows some slight increase on deposits.

The data summarized below, shows that although exports and imports are again larger in Albania and Kosovo, the trade deficit is almost on the same level 2.2 billion euros in 2012.

Table 2. Main Macroeconomic indicators

\begin{tabular}{|l|c|c|c|c|c|c|c|c|}
\hline & \multicolumn{4}{|c|}{ Albania } & \multicolumn{4}{c|}{ Kosovo } \\
\hline & $\mathbf{2 0 1 0}$ & $\mathbf{2 0 1 1}$ & $\mathbf{2 0 1 2}$ & $\mathbf{2 0 1 3}$ & $\mathbf{2 0 1 0}$ & $\mathbf{2 0 1 1}$ & $\mathbf{2 0 1 2}$ & $\mathbf{2 0 1 3}$ \\
\hline Real GDP growth & $3.80 \%$ & $3.10 \%$ & $1.60 \%$ & $1.4 \%$ & $3.20 \%$ & $4.50 \%$ & $3.80 \%$ & $3.10 \%$ \\
\hline GDP Mil Euro & $8,781.4$ & $9,186.7$ & 9,539 & NA & $4,136.0$ & $4,486.0$ & $4,895.50$ & $5,041.0$ \\
\hline Avarage inflation & $3.60 \%$ & $3.50 \%$ & $2 \%$ & $1.9 \%$ & $3.50 \%$ & $7.30 \%$ & $2.50 \%$ & $1.80 \%$ \\
\hline Loans (mil euro) & $3,505.8$ & $3,862.4$ & $3,990.6$ & 3,921 & $1,458.7$ & $1,698.1$ & $1,763.40$ & $1,805.8$ \\
\hline Deposits (mIn euro) & $5,698.0$ & $6,238.0$ & $6,695.7$ & 6,786 & $1,936.9$ & $2,104.0$ & $2,279.00$ & $2,449.0$ \\
\hline Exports mIn euro) & $1,171.0$ & $1,405.0$ & $1,525.0$ & $1,756.20$ & 294 & 312.5 & 269.3 & 293.9 \\
\hline Imports (mIn euro) & $3,254.0$ & $3,647.0$ & $3,524.0$ & $3,475.90$ & $2,144.9$ & $2,479.0$ & $2,499.0$ & $1,992.0$ \\
\hline
\end{tabular}

Source: BoA,BPK, INSTAT, CBK annual report 2013

A detailed analysis may reveal clearer comments for this fact, it shows large dependence on imports of both economies. For more, great efforts and special programs should be designed to encourage domestic production - which directly affects employment growth and fiscal performance in Albania and Kosovo. The financial sector in Albania and in Kosovo is relatively new with institutions that rely more on banking activity than other financial intermediaries like the stock market.

Table 3. The structure of the system of total financial sector assets in $\%$

\begin{tabular}{|c|c|c|}
\hline & Albania & Kosovo \\
\hline & 2012 & 2012 \\
\hline Banking sector & 93.5 & 73.7 \\
\hline Non banking institution & 2.7 & 0.0 \\
\hline Insurance companies & 1.6 & 3.4 \\
\hline Pensions funds & 1.2 & 19.6 \\
\hline Microfinance & 0.1 & 3.3 \\
\hline Investments funds & 0.8 & $\mathrm{NA}$ \\
\hline
\end{tabular}

Source: BOA, CBK annual report 2012 
From the data reported for the specific weight of the financial actors to the total system, we comment as follows.

- The banking dominance of Albania is extremely high: $93.5 \%$ in 2012 compared with $73.7 \%$ in the financial system for the same year for Kosovo.

- Insurance companies, although in Kosovo had fewer years of activity than in Albania; have a greater share from the total financial sector. However the share to total sectors is relatively low in only 3.4 percent in Kosovo.

- There was no Legacy of pension funds of ex Yugoslavia in Kosovo, therefore the development of private pension funds have made these companies own 19.6\% of total financial sector assets (15.3 percent of GDP), which represents the second largest system within the financial sector in Kosovo. While in Albania, state supported a scheme is still a "strong barrier" for private development (private pensions occupy only 1.2\%).

Table 4. Weight of components of banking system assets to total (in\%)

\begin{tabular}{|c|c|c|}
\hline & Albania & Kosovo \\
\hline & $\mathbf{2 0 1 2}$ & $\mathbf{2 0 1 2}$ \\
\hline Total assets & 8,546 & 2,652 \\
\hline CASH and CB balance & 0.6 & 11.3 \\
\hline Comercial banks Balance & 12.8 & 10 \\
\hline Securities \& TB & 35.4 & 8.1 \\
\hline Loans & 48.2 & 67 \\
\hline Fix assets & 1 & 1.9 \\
\hline Other assets & 2 & 1 \\
\hline Total & 100 & 100 \\
\hline
\end{tabular}

\section{Source: $B O A, C B K$}

What stands out in the above table is the biggest supporter of the banking system of Albanian government borrowing. The relationship of domestic debt financing apparently keeps the Albanian system to support investment in government security $35.5 \%$ of total assets compared to $8.1 \%$ in Kosovo. Obviously this is reflected directly on supporting business with loans. In Kosovo uses 67\% of assets in loans, compared with 48\% in Albania. Sources of funds of the banking system, as in Albania and in Kosovo, are mainly deposits around 80\%.

Table 5. Banking system liabilities structure

\begin{tabular}{|c|c|c|}
\hline & Albania & Kosovo \\
\hline & $\mathbf{2 0 1 2}$ & $\mathbf{2 0 1 2}$ \\
\hline Totla of liabilities(mln euro) & 8,546 & 2,652 \\
\hline Other Banks & 5.4 & 0.8 \\
\hline Deposits & 82.4 & 79.5 \\
\hline Other loans & 0 & 1 \\
\hline Other liabilities & 2.1 & 7.8 \\
\hline Other financial assets & 10.1 & 10.8 \\
\hline Sum & 100 & 100 \\
\hline
\end{tabular}

\section{Source: BOA, CBK}

Obviously, the volumes of assets do not provide directly any clear idea about bank performance, so in order to compare the banking system in Albania and Kosovo we have analyzed some indicators that are summarized in the table below. 
Table 6. Performance indicators of banking system.

\begin{tabular}{|c|c|c|}
\hline & Albania & Kosovo \\
\hline & $\mathbf{2 0 1 2}$ & $\mathbf{2 0 1 2}$ \\
\hline Banking system profit(mln euro) & 27,3 & 19,2 \\
\hline Nonperforming loans & $22.5 \%$ & $6.1 \%$ \\
\hline Loans/Deposits ratio & $58.8 \%$ & $77.4 \%$ \\
\hline Capital adequacy ratio & $16.2 \%$ & $18.8 \%$ \\
\hline Risk weighted assets (mln euros) & $4,776.90$ & 1,730 \\
\hline Banking system capital(mln euro) & 732,4 & 310,0 \\
\hline ROA & $0.33 \%$ & $0.9 \%$ \\
\hline ROE & $3.8 \%$ & $9 \%$ \\
\hline
\end{tabular}

\section{Source: BOA, BQK}

\section{Comparison of Performance Indicators in the Banking Systems of Albania and Kosovo}

Banking system in total appears with 27.3 million euro profits in Albania and 19.2 million in Kosovo. Not wanting to step in more detail of this indicator we suggest that profit performance in the Albanian system should be greater, since the size of the resource that is available in comparison with Kosovo is several times greater. Those, who"undermines" profit seems to be bad loans (22.5\% for Albania) but, also indirectly ROE (return on equity ratio). Albanian banking business owners won only 3,5\%, while in Kosovo 9\% despite greater exposure to credit. The capital adequacy ratio is indicated over the maximum rate of (12\%) that the Basel Accord refers: $16.2 \%$ and $18.8 \%$ for Albania and Kosovo. The data risk weighted assets noted that the Albanian system is 2.7 times much exposed to risks, which create a "threat" to the performance which verifies the increase of provision for bad loans as extra costs of the system.

The biggest beneficiaries of loans in the banking system of Albania and Kosovo are businesses and families with $95 \%$ of the total

Table 7. Loans Beneficiaries in \%

\begin{tabular}{|c|c|c|}
\hline & Albania & Kosovo \\
\hline & $\mathbf{2 0 1 2}$ & $\mathbf{2 0 1 2}$ \\
\hline Families & $26.3 \%$ & $30.7 \%$ \\
\hline Businesses & $70.1 \%$ & $67.0 \%$ \\
\hline Others & $3.6 \%$ & $2.3 \%$ \\
\hline Sum & $100 \%$ & $100 \%$ \\
\hline
\end{tabular}

\section{Source: $B O A, C B K$}

Stages of economic development and banking business are depending on each country's macroeconomic policies. Banks normally are profit-oriented businesses, while regulators monetary and economic policies need to channel the financing of businesses for the benefits of the society. The short history of the Albanian banking system has shown considerable support in the early stages of the construction and commerce business. The dates on the distribution of loans of economic activity in Albania and in Kosovo give us an insight to some orientations of financial intermediation in the two countries. 
Table 8. Distribution of loans of economic activity

\begin{tabular}{|c|c|c|}
\hline Indices in \% & Albania & Kosovo \\
\hline Agriculture & $\mathbf{2 0 1 2}$ & $\mathbf{2 0 1 2}$ \\
\hline Hostelry & 1.4 & 9.0 \\
\hline Commerce & 4.1 & 7.9 \\
\hline Construction & 33.1 & 4.7 \\
\hline Production & 18.2 & 25.6 \\
\hline Mining industry & 14.8 & 27.2 \\
\hline Other services & 1.7 & 7.3 \\
\hline Health care & 7.7 & 18.3 \\
\hline Education & 1.2 & $\mathrm{NA}$ \\
\hline Financial mediation & 1.1 & $\mathrm{NA}$ \\
\hline Transportation Communication & 2.9 & $\mathrm{NA}$ \\
\hline Energy industry & 2.8 & $\mathrm{NA}$ \\
\hline Sum & 11 & $\mathrm{NA}$ \\
\hline & 100 & 100 \\
\hline
\end{tabular}

\section{Source: $B O A, C B K$}

It can not be expressed any opinion on the margin of mediation, as it is an indication that in Albania is weighted by the two currencies (lek and euro) and in Kosovo only in euros. Moreover, the opinions of this margin should be strengthened with the effectiveness of the transmission mechanism of monetary policy.

The international administration in Kosovo is a regulator that applies internationally recognized standards for positively imapact in business management. Agriculture as a vital activity that supports the production and families living in Kosovo takes about 9\% of loans, while the figure in Albania is very low: $1.4 \%$.

Construction and Production in Kosovo take about $50 \%$ of loans from banks and Hostelry has about 2 times more loans than in Albania (compared in relative terms). The construction boom in Albania belongs years ago. While, government policies are promoting investment in energy production (about $29 \%$ for these two sectors).

Trade in Albania "absorbs" one third (1/3) of total loans to the banking system, while production relies only on $15 \%$ of total loans from banks.

Above mentioned, banks as profitable businesses and this is easily verifiable from this "geography" of the distribution of loans. Comparability, in this paper, between the banking systems in Albania and in Kosovo urges us to give some claims or a recommendation in the benefits of a market thus has the same tradition and language

\section{Conclusions Remarks}

A result from the analysis of comparison of the banking system in Albania and Kosovo indicates that two -level banking system have a relatively short history as a result of political and economic factors. However, the banking systems in both countries represent development inside the financial sector, and both systems seem to be well established, and profitoriented businesses. This is shown by the specific weight that banking system assets occupy to the entire financial sector assets in both countries that are respectively $93 \%$ and $74 \%$ for Albania and Kosovo. In both countries, foreign capital dominates the financial system/banking expertise and institutional culture is therefore not lacking.Thus, both banking systems dominate foreign banks respectively $92 \%$ and $90 \%$ in the banking structure.

Although, as it observed developments in the banking systems of the two countries are still considered positive, cash economy occupies an important weight in transactions realized in these economies. The level of competition in the banking systems of the two countries is still low which is shown by the high level of banking concentration in the two countries where the concentration is significantly higher in Kosovo. In the structure of the Albanian banking system, assets are somewhat more diversified than in Kosovo. This is mainly due to the fact that aside from lending to the economy, commercial banks in Albania finance significantly the government necessity for the loan. This is related to the development of the Albanian loan market that uses Treasury Bills as a way of investment, instruments that are not present in the economy of Kosovo.

Without excluding, that the global financial crisis has affected both bankig systems as a whole in recent years, 
performace indicators continue to be positive but with a descending trend. Banking system in general (having separate banks that have resulted in losses) is resulting from profits. Here we found agriculture as a key sector in both countries, which is supported by little or no by banking systems of Albania and Kosovo.

The support of the economy with bank loans in both countries can be considered insufficient, seen this from the indication of financial intermediation that continues to be low in both countries. Credit risk represents a problem that concerns both banking systems; however, it is higher in the Albania banking system, shown in the index of nonperforming loans which are now about $26 \%$ of the total loan portfolio. Risk prediction and the use of modern techniques and methods of measuring it, takes great importance today in both countries. Most of the loans to the economies of both countries by commercial banks are ensured by real estate. If, there is a potential risk of a collapse of the real estate market it will be transferred to an increased risk that banks will own a property, maybe with a less value than the value of the loan itself. Additional effort is seen to be required in both banking systems, for future performance.

- The lack of a capital market in both countries should be considered as a barrier to the development indicators of banking systems.

- The cost of lending by commercial banks of the two countries should be considered high.

- Analysis and management of bank credit risk in both banking systems is a very important process and should be given maximum attention in order to minimize it.

- Increased loan portfolio requires careful monitoring in the process of examining the quality of the loan portfolio.

- It is necessary to monitor the indicator of increasing non-performing loans. An Important role here should play the Bank of Albania and Kosovo Central Bank as the country supervisory authorities.

- Reducing interest rates of the two countries economies require a multidimensional approach, and in this aspect it is very important, to further increase competition in the banking system, to enhance opportunities for financial crediting and to improve the judicial system.

- The difficulties come from financial mediation and the situation can be improved by developing a better relation of individuals, families and businesses with banks, thus promoting and providing more effective banking services in recommended.

\section{References}

Annett, A. (2005). House prices and monetary policy in the euro area. Chapter III in Euro area policies: selected issues, IMF Country Report, (05/266).

Bernanke, B. S., \& Gertler, M. (1986). Agency costs, collateral, and business fluctuations.

Bernanke, B. S., \& Gertler, M. (2001). Should central banks respond to movements in asset prices?. american economic review, 253257.

Blejer, M. I. (2007). Asset prices, globalization, and implications for monetary policy. Comparative Economic Studies, 49(3), 339-344.

Égert, B., \& Mihaljek, D. (2007). Determinants of house prices in Central and Eastern Europe. Comparative economic studies, 49(3), 367-388.

Feldstein, M. S. (2007). Housing, credit markets and the business cycle (No. w13471). National Bureau of Economic

Research.

Fitzpatrick, T., \& McQuinn, K. (2007). HOUSE PRICES AND MORTGAGE CREDIT: EMPIRICAL EVIDENCE FOR IRELAND*. the manchester school,75(1), 82-103.

Goodhart, C., \& Hofmann, B. (2003). Deflation, credit and asset prices. Hong Kong Institute for Monetary Research Working Paper, 13, 2003.

Lowe, P., \& Borio, C. (2002). Asset prices, financial and monetary stability: exploring the nexus (No. 114). Bank for International Settlements.

Shelburne, R. C., \& Palacin, J. (2006). Is There an East European Housing Bubble?. Global Economy Journal, 6(3).

Raporti vjetor i Bankes se Shqiperise 2008, 2009, 2010, 2013; www.bankofalbania.org

Banka Qendrore e Republikës së Kosovës - Buletini i sektorit financiar, Prishtinë, 2010; www.bqk-kos.org

Raporti vjetor i Bankes Qendore te Kosoves për vitin 2010, 2011, 2012, 2013, Prishtinë; www.bqk-kos.org

Parashikimi i BQK-së për Ekonominë Kosovare 2010 dhe 2011; www.bqk-kos.org

Banka Qendrore e Kosovës, raport i kredive të lëshuara në Kosovë në vitin 2010 dhe 2011; www.bqk-kos.org

Raporti mujor statistikor/Monthly statistical report; Central Bank of Albania; 2014; www.bankofalbania.org

Financial Sector Sector Assessment; Republic of Kosovo; Aprill 2013; www.imf.org/external/pubs/ft.../cr1399.pdf 